Debreceni Jogi Múhely 2021. (XVIII.) 1-2.

Debreceni Egyetem, Állam- és Jogtudományi Kar, Debrecen

(University of Debrecen, Faculty of Law, Debrecen)

DOI 10.24169/DJM/2021/1-2/6

Szabó Mercédesz Ibolya

PhD ballgató

Debreceni Egyetem, Marton Géza Állam-és Jogtudományi Doktori Iskola

\title{
A MUNKAIDŐ EGYOLDALÚ MEGHATÁROZÁSA A HATÁLYOS MUNKAJOGI SZABÁLYOZÁSBAN
}

Debreceni Jogi Műhely, 2021. évi (XVIII. évfolyam) 1-2. szám (2021. szeptember 1.)

DOI 10.24169/DJM/2021/1-2/6

Abstract: In most cases, law does not differentiate between various people in equal-level positions of a contract; during sales, the State has the same rights and obligations as the contracting private person. Labor law is a specific field of law where one of the parties that are theoretically on equal level - i.e. the employee - is actually in a somewhat subordinated and obviously more exposed position. In the light of the foregoing, it is especially notable that there are some fields of labor right where the third way applies; parties are not equally positioned in terms of power; however, it is not the employee who gets legal assistance for the equality of opportunities, but the law itself supports their disadvantaged position. Such situation is called the legal situation of unilateral power, and we aim to study to what extent it is present in Hungarian labor law and how advantageous or disadvantageous this it to the parties. The field of law where one is likely to detect the traces of unilateral power is the legal regulation related to working time, which, therefore, is the subject of this study, and the definition of working time will hereinafter be looked into from the aspect of the employer's unilateral right to establish employment. Unilateral power is basically not typical to be enforced in labor law, and therefore, working time-related regulations - that belong to the employer's own discretion - form an exception in such respect. At the same time, the option of flexible work order provides an exception from the superiority of unilateral power, and therefore it is actually an exception to the exception. Such complex system, however, provides the option to make sure whether the enforcement of unilateral power is constructive in labor law, or it would be more reasonable to apply a more balanced system such as the principle of the employer's ultima ratio as suggested by Guy Davidov. While noting that according to those described above, flexible work order poses some potential risks, too, in our opinion, it would be more efficient and social to set up a consensus-based system, which would also allow us to satisfy our obligation of European Union legal harmonization. Hungarian legislation, and labor law legislation in particular has numerous tasks to do in order to promote the solution of socio-economic problems, as well as to fulfil our obligations related to legal harmonization; in our opinion, the conclusions above confirm that making working time regulations more liberal is one of the major tasks of legislation.

Keywords: labor law, disadvantaged position, unilateral power, working time

Absztrakt: A jog a legtöbb esetben nem különbözteti meg a szerződés mellérendelt pozícióiban lévő különböző személyeket - az állam is azonos jogokkal és kötelezettségekkel rendelkezik egy adásvétel során, mint magánszemély szerződő partnere. A munkajog kifejezetten az a jogterület, ahol az elméletileg teljesen mellérendelt felek közül az egyik - a munkavállaló - a valóságban mindig alárendeltebb és nem kétségesen kiszolgáltatottabb helyzetben van. A fentiek tükrében kifejezetten figyelemre méltó, hogy a munkajogi szabályozásnak mégis vannak olyan területei, ahol éppenséggel a harmadik út érvényesül - nem azonos erôpozícióban vannak a felek, de nem a munkavállaló kap jogszabályi segítséget esélyegyenlőségéhez, hanem handicap helyzetét maga a jog erősíti. Ezt a helyzetet nevezzük a hatalmasság jogi helyzetének és célunk annak megvizsgálása, milyen mértékben van ez jelen a magyar munkajogban és mennyire előnyös vagy hátrányos ez bármelyik oldal számára. Az a munkajogi terület, ahol leginkább felfedezhetjük a hatalmasság nyomait, az a munkaidővel kapcsolatos jogi szabályozás, amely így a jelen tanulmány tárgyát képezi s a továbbiakban a munkaidő fogalmát a munkáltató egyoldalú jogviszony alakítási jogkörének aspektusából 
Debreceni Jogi Múhely 2021. (XVIII.) 1-2.

Debreceni Egyetem, Állam- és Jogtudományi Kar, Debrecen

(University of Debrecen, Faculty of Law, Debrecen)

DOI 10.24169/DJM/2021/1-2/6

vizsgáljuk. A munkajogra alapvetően nem jellemző a hatalmasság érvényesülése, így a munkaidővel kapcsolatos szabályok - amelyek túlnyomórészt a munkáltató diszkrecionális jogkörébe tartoznak - ilyen tekintetben kivételnek számítanak. A kötetlen munkarend lehetősége ugyanakkor a munkaidővel kapcsolatos hatalmasság - fölény alól jelent kivételt, így tulajdonképpen a kivétel kivétele. Ez a bonyolultnak tűnő rendszer mindazonáltal lehetőséget ad arra, hogy meggyőződjünk arról, hogy építő jellegú-e a hatalmasság érvényesülése a munkajogi szabályozásban vagy célszerúbb lenne egy kiegyenlítettebb rendszer alkalmazása, akár a Guy Davidov által javasolt munkáltatói ultima ratio megoldásával. Megjegyezve, hogy a fent is említettek szerint a kötetlen munkarend is rejt magában veszélyeket, álláspontunk szerint hatékonyabb és szociálisabb lenne egy konszenzusos rendszer kialakítása, amellyel nem mellesleg Európai Uniós jogharmonizációs kötelezettségeinknek is eleget tennénk. Jogalkotásunk s így munkajogi jogalkotásunk előtt számos feladat áll társadalmi - gazdasági problémák megoldásának elősegitése illetve a jogharmonizációs kötelezettségek teljesítése érdekében - a fenti megállapítások álláspontunk szerint alátámasztják, hogy a munkaidő szabályozásának liberálisabbá tétele a jogalkotásunk előtt álló fontos feladatok közé tartozik.

Kulcsszavak: munkajog, hátrányos helyzet, egyoldalú hatalom, munkaidő

\section{Bevezetés}

A jog a legtöbb esetben nem különbözteti meg a szerződés mellérendelt pozícióiban lévő különböző személyeket - az állam is azonos jogokkal és kötelezettségekkel rendelkezik egy adásvétel során, mint magánszemély szerződő partnere.

Nem egy esetben azonban kimondott - kimondatlan célja a jogalkotónak, hogy a különböző pozíciókban lévő, elvben egyenrangú jogalanyok tényleges helyzetéből adódó esélyegyenlőtlenségét kiegyenlítse vagy legalábbis csökkentse a pozíciók közötti szakadékot.

A munkajog kifejezetten az a jogterület, ahol az elméletileg teljesen mellérendelt felek közül az egyik - a munkavállaló - a valóságban mindig alárendeltebb és nem kétségesen kiszolgáltatottabb helyzetben van.

„A munkajog tehát egy felborult egyensúlyi állapotban lévő jogviszonyt szabályoz, felismervén azt is, hogy alanyai gyakran a gazdasági forgalom nem egynemú szereplői. Az, hogy miként próbálja a munkajog helyreállítani az egyensúlyi állapotot, visz a szabályozás módszere felé. Így az egyik lehetőség, hogy direkt módon a gyengébb felet védő kógens normákat emel kötelezően a jogviszonyba.” (Bodó, 2011)

A munkajog egyértelmúen a citált lehetőséget választja, klaudikáló jogfelfogásával, mint klasszikus szinallagmatikus kötelem a felek számára számos ponton szándékosan és kimondva különböző jogi lehetőséget biztosít, ezzel igyekezve a rendkívül erőteljes esélyegyenlőtlenséget kiegyenlíteni - tudva, hogy ez teljesen soha nem fog sikerülni.

Ez, a szerző által megjelölt megoldás álláspontunk szerint helyes és követendő, mind a szociális biztonság, mind a gazdaság múködése és hatékonysága olyan kardinális jelentőségú állami feladat, amely indokolttá, sőt szükségessé teszi a jogviszonyok alakításába történő direkt beavatkozást - ennek a beavatkozásnak hiányában ugyanis mind a munkavállalók szociális biztonsága, mind a gazdaság stabilitása megkérdőjeleződne.

A fentiek tükrében kifejezetten figyelemre méltó, hogy a munkajogi szabályozásnak mégis vannak olyan területei, ahol éppenséggel a harmadik út érvényesül - nem azonos erôpozícióban vannak a felek, de nem a munkavállaló kap jogszabályi segítséget esélyegyenlőségéhez, hanem handicap helyzetét maga a jog erősíti. Ezt a helyzetet nevezzük a hatalmasság jogi helyzetének és célunk annak megvizsgálása, milyen mértékben van ez jelen a magyar munkajogban és mennyire előnyös vagy hátrányos ez bármelyik oldal számára.

Az a jogterület, ahol leginkább felfedezhetjük a hatalmasság nyomait, az a munkaidővel kapcsolatos jogi szabályozás, amely így a jelen tanulmány tárgyát képezi s a továbbiakban a munkaidő fogalmát a munkáltató egyoldalú jogviszony alakítási jogkörének aspektusából vizsgáljuk. 
Debreceni Jogi Múhely 2021. (XVIII.) 1-2.

Debreceni Egyetem, Állam- és Jogtudományi Kar, Debrecen

(University of Debrecen, Faculty of Law, Debrecen)

DOI 10.24169/DJM/2021/1-2/6

\section{A munkaidő általános szabályai}

A munkaidő hazai szabályozása általánosságában is erôsen vitatható, hiszen a részletszabályok a legkevésbé sem erősítik a munkavállalók pozícióit, ellenkezőleg kedvezőtlenek a munkavállalói oldal számára, és kétséges az Európai Unió jogi szabályozásával kapcsolatos jogharmonizációs kötelezettség teljesülése is. A munkaidő a munkajogviszony esszenciális elemei közé tartozik, hiszen ez az az idôtartam, amikor a munka végzésére sor kerül, amikor a munkajogviszony ténylegesen aktív státuszba kerül.

A munkaidő kérdése kardinális jelentőségű a munkajogi szabályozásban, a Munka Törvénykönyve előkészítése során is ez okozta talán a legélesebb vitákat, amiről Prugberger Tamás is jóstehetségről tanúbizonyságot tevő sorokat írt, mikor is kifejtette a Széll Kálmán terv és az új Széchenyi terv a gazdaságot és a foglalkoztatást fellendítő, ugyanakkor az államháztartás egyensúlyát helyre állító hatásaival kapcsolatos nézeteit, amelyek értelmében mindez óhatatlanul a Munka Törvénykönyv módosításával is együtt jár majd, ami nem a munkavállalók, hanem a munkáltatók számára fog kedvezóbb helyzetet eredményezni. (Prugberger, 2011)

Prugberger Tamás gondolatai előre látható következményeket vázoltak fel s igaza volt, a hatályos munkajogi kódexünk munkaidő szabályozása nemhogy nem a munkavállalóknak kedvező, de még az Európai Unió jogszabályaival sem kompatibilis. Természetesen a gazdaság fellendülése és stabilitása mindenkinek, így a munkavállalói oldalnak is érdeke és meggyőződésünk szerint a munkáltató nyereséges gazdálkodása s ennek nyomán a munkahely fennmaradása, a körülmények javíthatósága, a szociális kiadások bóvitésének lehetősége mindkét oldal számára egyaránt fontos tényező. Az sem vitás, hogy ezekért a célokért mindkét oldalnak áldozatokat kell hozni, a problémát inkább az veti fel, hogy a munkajogi hatalmasság érvényesülése folytán a munkavállalói oldal a munkaidő terén csekélyebb befolyással rendelkezik, miként, milyen mértékű áldozatot akar hozni.

A munkaidő vonatkozásában jogalkotásunk nem harmonizál az Európai Unió jogával, ahogy Fodor T. Gábor fogalmaz: megvizsgálta és megállapította, hogy „a magyar munka- és pihenőidős szabályrendszer komoly hiányosságokkal vette át - pontosabban inkább nem vette át - a vonatkozó 2003/88/EK irányelv szabályait." (Fodor, 2016, p. 21)

Fodor T. Gábor megállapításait 2016-ban, pár évvel a hatályos kódex megalkotása után írta le, azonban 2019-ben, az Európai Bíróság (Második Tanács) a Syndicat des cadres de la sécurité intérieure valamint a Premier ministre, a Ministre de l'Intérieur, a Ministre de l'Action et des Comptes Publics között folyamatban volt eljárásban hozott C-254/18. számú döntése (Európai Unió Bírósága (második tanács) ítélete a C-254/18. számú ügyben) apropóján a szerző újabb tanulmányában megerősítette, hogy álláspontja szerint jelentős problémák mutathatóak ki a magyar jog munkaidős szabályainak uniós megfelelőségével kapcsolatban. (Fodor, 2019)

Prugberger Tamás és Fodor Gábor fenti megállapításait az eltelt időszak tapasztalatai csak megerősítették, a Munka Törvénykönyve nem nyert olyan módosítást, ami jogharmonizációs feladataink során valós előrelépést jelentett volna. A hazai munkajogi kódex már megalkotásakor sem volt kedvező a munkaidő szempontjából, azóta bekövetkezett módosításai a szabályozás egyoldalúságán nem változtattak, sốt a munkavállalói oldal pozícióját tovább rontották, amint Prugberger Tamás megállapítja: „Sôt több vonatkozásban az irányelv intencióival és a régi tagállamok szabályozásával szemben szigorúbb elóírásokat vezetett be az új Mt., ami elsősorban a túlmunka és a rendkívüli munkavégzés lehetőségének a növelésében, valamint a túlmunka és a rendkívüli munkavégzés után járó bérpótlékok csökkentésében, sôt a munkáltató egyoldalú döntésével a bérpótlékot szabadidôvel történő kiváltásában jelentek meg. ugyanakkor az új mt. általános jelleggel - a korábbi mt. szerinti kivételes szabályt felülírva, a munkaidő mértékét az irányelvvel összhangban rendezte.” (Prugberger, 2017, p. 31-32)

A hatályos Munka Törvénykönyve XI fejezete tartalmazza a munkaidôvel kapcsolatos szabályokat, amelyek között egyaránt találunk konszenzussal alakítható és a munkáltató egyoldalú akaratával formálható elemeket, vizsgálódásunk tárgyát értelemszerúen az utóbbiak képezik, áttekintésüket megelőzően azonban szükséges a munkaidő fogalmi meghatározása. 
Debreceni Jogi Múhely 2021. (XVIII.) 1-2.

Debreceni Egyetem, Állam- és Jogtudományi Kar, Debrecen

(University of Debrecen, Faculty of Law, Debrecen)

DOI 10.24169/DJM/2021/1-2/6

\section{A munkaidő meghatározása általában}

Antagonisztikus vitás kérdés a munkajogviszony vizsgálatakor, hogy a munkáltató és a munkavállaló ellenérdekű félnek minősül-e. Szélsőséges megközelítések szerint a munkáltató gyakorlatilag kizsákmányolja a munkavállalót, a munkavállaló pedig természetes ellensége a munkáltatónak, míg a másik véglet gyakorlatilag szövetségesként tekint a munkajogviszony két alanyára.

Adam Smith életmúve ezt a két szemléletet egyetlen tudós múveiben is kifejezésre juttatja. A nemzetek gazdasága című múvében a klasszikus munka-értékelmélet meghatározó képviselőjeként a munka és a tôke közötti csere problémájaként határozza meg, hogy a tőkés a munkabérnél nagyobb értéket kap a munkástól, ugyanakkor Az erkölcsi érzelmek elmélete címú alkotás a közösségi szolidaritást tekinti a társadalmi tevékenység alapjának. (Smith, 1959, 1977)

Karl Marx a Tőke címú mûvében ugyanakkor a klasszikus munka-értékelméletet immáron az osztályharcelmélet irányában fejlesztette tovább (Marx, 1955), a kisajátítható értéktöbblet keletkezésének, a tőkés társadalmi viszonyok kizsákmányoló jellegének a magyarázatául is megjelöli. (Szentes, 2018)

Az Európai Unió Alapjogi Chartája ugyanakkor „Szolidaritás” megjelöléssel illeti a 27-33. cikkekben foglalt munkajogi deklarációit, ezzel is kifejezve, hogy a munkajogviszony két oldalára nem úgy, mint ellenségekre gondol. Amint Zaccaria Márton Leó rámutat, az Európai Bíróság 198/13 számú ítélete fenntartja a munkavállalók szociális és gazdasági veszélyeztetettségét, relatívvá téve a Charta vívmányait azzal, hogy „az alapjogokon keresztül nem kíván beavatkozni a felek munkaerőpiaci - gazdasági - autonómiájába." (Zaccaria, 2017. p. 98)

Az igazság vélhetően - szokás szerint - középúton található, az azonban mindenképpen tény, hogy a munkavállaló tipikusan szeretne minél magasabb fizetést kapni minél rövidebb időtartamú munkavégzés ellenében, míg a munkáltató az ellenkezőjét szeretné elérni, erre az álláspontra helyezkedik a jogtudomány az alábbi értelmezés során is:

„Az ellenérdekű felek a munkaszerződést abból a célból kötik, hogy az ennek alapján létrejövő munkajogviszony keretében az egyik fél (munkavállaló) munkaerejét díjazás ellenében a másik szerződő fél (munkáltató) rendelkezésére bocsássa és számára rendszeresen (ismétlődően) valamilyen munkatevékenységet végezzen." (Pál, 2018, p. 104)

A munkaidő meghatározásakor érdemes idéznünk az Európai Unió jogalkotásának eredményeit, valamint a hazai munkajogi kódexet egyaránt:

Az Európai Unió legfontosabb vonatkozó jogi aktusa, a 2003/88/EK irányelv 2. cikk 1. pontjának munkaidő meghatározása az alábbi: „Munkaidő: az az időtartam, amely alatt a munkavállaló dolgozik, a munkáltató rendelkezésére áll, és tevékenységét vagy feladatát végzi a nemzeti jogszabályoknak és/vagy gyakorlatnak megfelelően”. (2003/88/EK Irányelve)

A Munka Törvénykönyve munkaidő-definícióját a kódex 86. \(1) bekezdésében találjuk: „Munkaidő: a munkavégzésre előírt idő kezdetétől annak befejezéséig tartó idő, valamint a munkavégzéshez kapcsolódó előkészítő és befejező tevékenység tartama”. (2012. évi I. törvény a munka törvénykönyvéről)

A két fenti definíció alapjaiban azonosnak tủnik, azonban részleteiben megvizsgálva azokat, nem elhanyagolható eltérések állapíthatók meg. Jelentős eltérés, hogy a hazai definíció a munkavégzésre elôírt idő kezdetétől annak befejezéséig tartó idő, valamint a munkavégzéshez kapcsolódó elókészítő és befejező tevékenység tartama alapján határozza meg a munkaidő tartamát, míg az Európai Unió szabályozása ennél szélesebben - abban az időtartamban, amely alatt a munkavállaló dolgozik, a munkáltató rendelkezésére áll, és tevékenységét vagy feladatát végzi - jelöli meg a munkaidő fogalmát. Ez az eltérés, a szélesebb megfogalmazás folytán, kifejezetten munkavállaló-barátabbá teszi az uniós irányelv definícióját, azonban a második, ezzel összefüggő eltérés a történelem bizonysága folytán minden kétséget kizáróan még fontosabbnak túnik.

Mint a Sipka Péter, Zaccaria Márton Leó szerzőpáros a kérdést részletesen feldolgozó munkájában megállapította, „a jogalkotónak olyan fogalmat kell alkotnia, amely a munka világának szereplói számára egyértelmű eligazítást ad arra nézve, hogy egy adott tevékenység munkaidőnek minősül-e, mert ez képezi a 
Debreceni Jogi Múhely 2021. (XVIII.) 1-2.

Debreceni Egyetem, Állam- és Jogtudományi Kar, Debrecen

(University of Debrecen, Faculty of Law, Debrecen)

DOI 10.24169/DJM/2021/1-2/6

felek közötti elszámolás alapját”. (Sipka - Zaccaria, 2016, p. 449)

Egy tipikus civilisztikai jogviszonyban a legfontosabb kérdés, hogy „mit kell csinálnom és mit kapok ezért”. Indokolt lenne ennek megfelelően, hogy legyen egy olyan definíciónk, ami segítséget nyújt a munkavállaló számára a „mit kell csinálnom” időbeli meghatározásához, azonban sajnos egyik definíció sem felel meg ennek az elvárásnak, hiszen a hazai megfogalmazás „a munkavégzéshez kapcsolódó előkészítő és befejező tevékenység tartama” tekintetében, míg az uniós irányelv „a munkavállaló ....... a munkáltató rendelkezésére áll” fogalmazásában nyilvánvalóan nem határozza meg elszámolásra alkalmasan a munkaidő fogalmát, mint az idézett mú is rögzíti: „A munkaidő egy látszólag egzakt, azonban szükségszerűen flexibilis fogalom is egyben, mind a magyar jogban, mind pedig az Európai Unió jogában”. (Sipka - Zaccaria, 2016, p. 449)

Ez a szükségszerú flexibilitás, pontosabban a szükségszerűség elfogadása ad utat a hatalmasság fokozott érvényesülésének a munkaidő szabályozása vagy éppen részleges szabályozatlansága terén. Álláspontunk szerint a flexibilitási szükségszerűségnek a felek konszenzusával történő szabályozása lényegesen kedvezőbb lenne a munkavállalói és így a munkavállalói oldal számára is (a hatalmasság gyakorlásánál lényegesen többet ér egy elégedett munkavállaló). rendkívül fontos jogtudományi - jogalkotási feladatnak tekinthető egy ilyen újszerű rendszer kidolgozása, mivel jelenleg jól látható, hogy a munkaidő szabályozása során „Mind a hatályos hazai, mind pedig az uniós szabályozásból jól kitűnik tehát, hogy egy adott időszak munkaidő jellegét nem a munkavégzés, hanem a munkáltató rendelkezése alapozza meg." (Pál, 2018, p. 108)

A munkaidő szabályozását semmiképpen sem képzelhetjük el egy konstans jogi állapotnak, a hazai törvényi szabályozás változásain túlmenően az Európai Unióban is új és új szabályozási elemek bukkannak fel „az Európai Unió Bírósága időrôl időre interpretálja ítéleteiben, ezáltal olyan újabb fejlemények mutathatók ki a munkaidő uniós jogi koncepciója kapcsán, amelyekkel számolni kell a tagállami jogalkotásban és joggyakorlatban is". (Sipka - Zaccaria, 2016, p. 449) Ezeknek a jogi újitásoknak az átvétele nem csak kötelességünk, de érdemes is jogfejlődésünk során azokat megfelelően alkalmazni, azonban még fontosabb feladatnak véljük, egy nem csak esetjogra alapozó, hazai komplex megoldás kidolgozását.

Az Európai Bíróság nagy jelentőségú vonatkozó döntései közül ki kell emelnünk az úgynevezett Tyco-ügyet, ahol az itélet meghozatalakor addig tabunak minősülő változásokat valósított meg a Bíróság.

A magyar jogban sajnos még teret egyáltalán nem nyert aktus „a C-266/14. számú ítélet (amely) explicit módon kimondja, hogy a munkaidő részét képezi a munkavállaló által utazással töltött idő abban az esetben, ha a munkavállaló nem rendelkezik állandó munkavégzési hellyel, és tényleges munkatevékenységét nem tudja rendszeres napi utazás nélkül teljesíteni”. (Sipka - Zaccaria, 2016, p. 449)

A Bíróság harmadik tanácsa C-266/14. számú ítéletében a Federación de Servicios Privados del sindicato Comisiones obreras (CC.OO.) valamint a Tyco Integrated Security SL és a Tyco Integrated Fire \& Security Corporation Servicios SA között folyamatban lévő eljárásban kimondta, hogy „a 2003/88 irányelv 2. cikkének 1. pontját úgy kell értelmezni, hogy az alapügyben szóban forgóhoz hasonló körülmények között, amikor a munkavállalók nem rendelkeznek állandó vagy szokásos munkavégzési hellyel, az e rendelkezés értelmében vett „munkaidőnek” minősül az utazási idő, amelyet e munkavállalók a lakóhelyük, valamint a munkáltatójuk által kijelölt első és utolsó ügyfél közötti mindennapos utazással töltenek". (Európai Unió Bírósága (harmadik tanács) ítélete a C-266/14. számú ügyben)

A „rendelkezésre állás”-ban töltött idő fogalmának esetenkénti kiterjesztése a lakóhely és a munkavégzés helye közötti úton töltött időre, igen nagy jelentőséggel bír a munkajogi joggyakorlatra és a jelen tanulmány tárgyára is - a Tyco - ügy és ennek a hazai munkajogba történő adaptálásának elmaradása nagy jelentőséggel bír.

A Sipka Péter, Zaccaria Márton Leó szerzőpáros rávilágít, hogy „A munkaidő helyes és pontos meghatározása a munkajogi szabályozás egyik leglényegesebb feladata, mivel ez jelenti a felek közötti teljesítés egyik alapvető referenciapontját... az európai bírósági gyakorlatban - de markáns módon a magyarban - sem merült fel eddig az itt tárgyalandó kérdés, ugyanakkor a Bíróság ítélete kifejezetten hozzáad a munkaidő 2003/88/EK irányelv szerinti fogalmához." (Sipka - Zaccaria, 2016, p. 450)

Jól látható, hogy míg az Európai Bíróság citált döntése jogi lehetőséget teremt az úton töltött idő munkaidőbe történő bevonására, ugyanakkor a hatályos magyar jog ezt egyértelműen kizárja, hiszen az Mt. 86. \ (3) bekezdése kógens korlátokat határoz meg a munkaidő kiterjesztésével kapcsolatosan, kategorikusan 
Debreceni Jogi Múhely 2021. (XVIII.) 1-2.

Debreceni Egyetem, Állam- és Jogtudományi Kar, Debrecen

(University of Debrecen, Faculty of Law, Debrecen)

DOI 10.24169/DJM/2021/1-2/6

kijelentve, nem munkaidő a munkavállaló lakó- vagy tartózkodási helyéről a tényleges munkavégzés helyére, valamint a munkavégzés helyéről a lakó- vagy tartózkodási helyére történő utazás tartama." (2012. évi I. törvény a munka törvénykönyvéről)

Ez a jogalkotói álláspont kizárja a lehetôségét annak, hogy a felek ettôl eltérően állapodjanak meg, illetve a munkavállalók jogos, esetleges munkáltatói túlzó elvásárokból származó igényeiket érvényesítsék. Figyelemmel a magyar jogalkalmazás szabályaira, arra sincs lehetőség, hogy egy bíróság adott ügyben az Mt. 86. \(3) bekezdésével ellentétes döntést hozzon. Ez az állapot sajnálatos módon nem kétségesen jogellenes, hiszen az Európai Bíróság esetjoga hazánk jogalkotását is kötelezi és a jogharmonizáció jegyében Magyarország is köteles lenne megadni a lehetőségét bizonyos esetekben az úton töltött időnek a munkaidőbe történő beszámítására.

Álláspontunk szerint a Tyco-ügy nyilvánvalóan nem azt jelenti, hogy az úton töltött idôt be kellene minden esetben számítani a munkaidőbe - változó munkahely (állandó munkavégzési hely hiánya) esetén szükséges így eljárni, de a beszámítás lehetôségét meg kellene teremteni, legalább méltánylást érdemlő körülmények esetén, ahogy azt az Európai Bíróság ítélete is tartalmazza. A javasolt komplex, teljeskörű szabályozás lényeges elemét képezné és kétségkívül úttörő jellegű lehetne egy tárgybeli, részletes, megengedő szabályozás.

\section{A hatalmasság szerepe és korlátai a munkajogban}

A munkajog az a speciális jogterület, amelynek elsődleges tárgya olyan jogviszony, amely kizárólag a felek konszenzusán alapuló szerzôdéssel jön létre s a teljes jogág szabályozási területe túlnyomórészt ennek a szerződéses jogviszonynak az egyedi vagy kollektív szabályozására koncentrál. Ezt a specialitást a Munka törvénykönyve szerkezete is igazolja: a kódex 5 részből, illetve 300 \$-ból áll, amiből 198 \a munkaviszonyra vonatkozó szabályozást (Második rész), 55 a kollektív szabályozást (munkaügyi kapcsolatokat) (Harmadik rész) tartalmazza s így mindössze 47 \marad a további három rész szabályozására. (2012. évi I. törvény a munka törvénykönyvéről.)

Más jogterületektől eltérően - ahol az egyoldalú akaratnak döntő jelentősége (büntetőjog, polgári jog birtokjog) van - a munkajogban a jogviszonyt alakító egyoldalú akarat jelentősége speciális. A Prugberger Tamás, Nádas György szerzőpáros megállapítása szerint „A munkajogviszonyban igen gyakoriak az egyoldalú jognyilatkozatok, mert a munkáltató utasítási joga gyakorlása során alkalmazza az egyoldalú jognyilatkozatot, amely jognyilatkozathoz természetesen az a joghatás füződik, hogy a munkavállaló az utasításban foglaltakat köteles teljesíteni.” (Prugberger - Nádas, 2014, p. 43)

Ez a megállapítás teljességgel helytálló, azonban a jogviszonyt alakító jognyilatkozatok terén a felek egyenlősége általában jellemző a szerződéses jogviszonyokra. A szerződés alapvetően feltételezi a felek mellérendeltségét és egyenlőségét és elképzelni sem tudja ennek a rendnek a felborulását.

Annak ellenére, hogy a munkajog tárgya a legtisztábban szerződéses jogviszony minden jogág közül, a munkajogban számos olyan klaudikáló rendelkezést találunk, amelyek - bár általában nem a jogviszony egyoldalú alakítását idézik elő - az egyik fél akaratának nagyobb érvényesülési lehetőséget biztosítanak. A munkaidő meghatározása azonban olyan esszenciális eleme a munkajogviszonynak, amely hasonló jelentőségủ a munkabér meghatározásához - a szolgáltatás és ellenszolgáltatás egyensúlya terén egyáltalán nem mindegy, hogy ugyanazért a fizetésért milyen munkarendben kell dolgozni a munkavállalónak.

Amint Kiss György megállapítja a munkajog fejlődésével kapcsolatos elemzése során: „A munkajog „szerződéses jog”, és mint ilyen, a felek akaratának részese, az erősek egyenlősége felé, abban megközelítésben viszont, hogy a jogalkotó és a jogalkalmazó akaratának is részese, a gyengék egyenlősége felé hajlik. Mivel az emberek ténylegesen nem egyenlők, a jognak mégis általában kell biztosítania az egyenlóséget, amely adott esetben egyes csoportok preferálását jelenti másokkal szemben - az egyenlőt egyenlően a nem egyenlőt nem egyenlően kezelni elve -, ezáltal újabb feszültségek keletkeznek, és ez önmagában is felveti az egyenlő fogalmának viszonylagosságát.” (Kiss, 2010, p. 5-6)

Az egyenlőség a munkajogban valóban rendkívül nehezen kezelhető fogalom. Egy olyan jogterületen, ahol rendkívül masszívan érvényesül az emberek közötti tényleges egyenlőtlenség, nem kétséges, hogy valamelyik 
Debreceni Jogi Múhely 2021. (XVIII.) 1-2.

Debreceni Egyetem, Állam- és Jogtudományi Kar, Debrecen

(University of Debrecen, Faculty of Law, Debrecen)

DOI 10.24169/DJM/2021/1-2/6

oldalnak prioritást kell adni. Ez a prioritást élvező oldal a munkajog területén általában a munkavállalói oldal. A munkajogi szabályozás bevallott célja a munkavállalói oldal kedvezôtlenebb helyzetének, gyengébb pozíciójának ellensúlyozása, sok esetben akár a szerződéses felek egyenlő helyzetének megingatása útján is.

Nem véletlen, hogy Kártyás Gábor megállapítja: „A munkajog tárgya, a munkaviszony sajátossága, hogy bár szerződéses alapozású magánjogi jogviszony, mégsem mellérendelt felek kapcsolata, hanem a munkáltató fölérendelt helyzetével jellemezhető.” (Kártyás, 2020, p. 43)

Ez a prioritás azonban nem tekinthető hatalmasságnak. A munkavállaló számára a jog megkönnyíti az igényérvényesítést, illetve korlátozza a munkáltató igényérvényesítési lehetőségeit, azonban nem adja meg a munkavállaló számára a lehetőséget arra, hogy egyoldalúan a munkajogviszony jelentős elemeit alakítsa, módosítsa.

Ugyancsak Kártyás Gábor állapítja meg Halmos Szilviával társszerzőségben, hogy „A 2012. július 1-jén hatályba lépett munka törvénykönyvéről szóló 2012. évi I. törvény (a továbbiakban: Mt.) legfontosabb célkitűzése a munkaerőpiac rugalmasságának növelése és a munkahelyteremtés volt. Az elmúlt évek alatt a munkaerőpiacon bekövetkezett változások révén azonban nem a foglalkoztatás bővítése, hanem a munkaerőhiány megoldása vált sürgős feladattá.” (Halmos - Kártyás, 2019, p. 152)

Jelenleg hatályos a pandémia okozta egészségügyi válsághelyzet, s amint Kiss György kérdezi: „van-e (munka)joga a válságnak?” (Kiss, 2020) a választ Berke Gyula adja meg, miszerint a válságra adott válaszok jogi hatása rendkívül speciális „A szabály lényege akként foglalható össze, hogy 'polgári jogiasította' a munkajogot, ha tetszik: a járványveszély okán kialakult krízishelyzetre úgy reagált, hogy az visszaállította a tradicionális, általában a szerződéses liberalizmus - megítélésem szerint valójában soha nem is létezett korszakára jellemző helyzet. Munkajogunk törvényi szabályait diszpozitívvá tette, s ezzel tulajdonképpen legalábbis átmenetileg - félretette a magyar munkajogban a politikai-gazdasági rendszerváltást követően az európai tapasztalatok alapján kialakított megoldásokat.” (Berke, 2020, p. 32)

A pandémia és szabályozása ennek megfelelően „eltüntette” a munkavállalói preferenciákat, lényegesen csökkentette az alapjogok érvényesülését a munkajogviszony keretei között is és így a hatalmasság érvényesülése ebben az időszakban a munkajogban példa nélküli a modern kor viszonylatában.

Pál Lajos a Glossa Iuridica hiánypótló jelentőségú különszámában megjelent tanulmányában rögzíti, hogy a munkáltatói oldal részéről nagyobb rugalmasságra van szükség a különleges helyzet kezelésére, ami többékevésbé meg is valósult, ez a rugalmasság azonban nem feltétlenül a munkavállalói érdekek előnyére szolgált, amint a szerző kijelenti, hogy a munkáltató számos olyan jogosultsághoz jutott a veszélyhelyzeti szabályozás által, amit „békeidőben” nem tehetne meg (például jogosult a munkaidőkeret alapjául szolgáló idôszakot elszámolási kötelesség nélkül meghosszabbítani). (Pál, 2020, p. 180)

A munkaidő vizsgálata során a teljesség igénye nélkül meg kell említenünk olyan, a pandémia kapcsán létfontosságú vált, speciális munkaidő megoldásokat, mint a részmunkaidős foglalkoztatás, illetve a távmunka, a home office.

Nem kétséges, hogy a munkahelyek válság alatti megőrzése, az emberek tömege elszegényedésének elkerülése és ugyanakkor a gazdaság talpra állíthatósága olyan priorítást élvező érdekhalmaz, amely áldozatokat követel. Az is ténykérdés, hogy rövid időre vonatkoztatva a hatalmasság erőteljes érvényesülése lényegesen elfogadhatóbb a társadalom számára, mint hosszú távon. Az elmúlt bő egy év eseményeiből azonban tanulnunk kell és megoldásokat kell kidolgozni az esetleg bekövetkező újabb válságok esetére, amelyek mindkét oldal számára kedvező opciókat jelentenek.

Jó útmutatót jelenthetnek például Radnay József megállapításai, miszerint „A munkaidő rugalmasabbá tétele az általános felfogás szerint a munkáltató érdekét szolgálja, ugyanakkor az mindkét fél érdekét is szolgálhatja. A munkavállaló érdekét azáltal, hogy lehetőséget ad a kisgyermekek vagy idős szülők támogatására, a munka és a családi élet közötti összhang biztosítására, de ugyanakkor a munkáltatók érdekei figyelembevételére, a munkaidô meghosszabbítására vagy a gyorsan változó fogyasztói igényekhez való alkalmazkodásra. Ennek eszköze lehet:

- a munkaidő csökkentése vagy egyéni munkaidő megállapítása kisgyermekek, beteg családtagok esetén, 
Debreceni Jogi Múhely 2021. (XVIII.) 1-2.

Debreceni Egyetem, Állam- és Jogtudományi Kar, Debrecen

(University of Debrecen, Faculty of Law, Debrecen)

DOI 10.24169/DJM/2021/1-2/6

- a részmunkaidőben foglalkoztatás elősegítése,

- a munkavállaló munkaideje a társa munkaidejéhez való hozzáigazításának lehetôvé tétele,

- időhitel-rendszer alkalmazása,

- idősebb munkavállalók munkaidejének csökkentése.” (Radnay, 2000, p. 15-17)

A részmunkaidő áttekintése során Zaccaria Márton Leó vonatkozó tanulmánya lehet zsinórmértékünk, mikor is megállapítja, hogy részmunkaidőben foglalkoztatott munkavállalónak tekinthetô az a munkavállaló, akinek a heti vagy a foglalkoztatási idô éves átlagában számított munkaideje kevesebb, mint az értelemszerűen vele összehasonlítható helyzetben lévő, teljes munkaidőben foglalkoztatott munkavállalóé. A szerző megállapítja, hogy az irányelv rendezi a teljes munkaidőben foglalkoztatott munkavállaló fogalmát is, ami szerint annak tekinthető, aki teljes munkaidőben végez munkát ugyanannál a munkáltatónál, ugyanolyan munkaszerződéssel, vagy munkaviszonnyal rendelkezik és ugyanolyan vagy hasonló munkát, vagy tevékenységet végez, figyelembe véve a további szempontokat is. (Zaccaria, 2011)

A tanulmánnyal egyetérthetünk akkor is, amikor rámutat, hogy a részmunkaidő célszerủ és mindkét fél részére egyaránt kedvező megoldás, azonban veszélyeket is rejthet magában, hiszen akár a diszkrimináció melegágya is lehet, s az Európai Bíróság Nagytanácsa a Nicole Wippel valamint a Peek \& Cloppenburg GmbH \& Co. KG közötti ügyben „a Bíróság tehát újra megerősítette, hogy objektív indokok hiányában semmiféle kedvezőtlen megkülönböztetés nem alkalmazható a részmunkaidőben foglalkoztatottakkal szemben”. (Európai Unió Bírósága (nagytanács) ítélete a C-313/02. számú ügyben)

Ténykérdés ugyanakkor, hogy legális vállalkozás és legális foglalkoztatás esetén a részmunkaidős foglalkoztatás összefüggésben van a vállalati méretekkel. Nagyobb arányú, illetve tömeges alkalmazásra elsősorban a nagyobb vállalatoknál van lehetőség. (Seres - Budai, 2013), illetve „A részmunkaidő alkalmazásának fontos befolyásoló tényezője a gazdasági tevékenység hullámzása vagy folyamatos jellege.” (Seres, 2014, p. 59)

A fenti megállapítások igazolják, hogy a részmunkaidős foglalkoztatás alkalmazása - bár a munkavállalók egyes csoportjai számára előnyük elvitathatatlan (Kismárton, é. n.) - egyértelmúen a munkáltató érdekeihez igazodik és kizárólag a munkáltató döntésén múlik. Természetesen ez nem csak pandémia idején, hanem általánosságban is érvényesülő tendencia.

A pandémia ugyan ideiglenesen változtatott a foglalkoztatási helyzeten, azonban biztosak lehetünk benne, hogy a korlátozások feloldása és a gazdaság mesterséges helyreállitása a status quo helyreállításával fog járni. A hatalmasság a munkaidő vonatkozásában azonban „békeidőben” is érvényesül, ennek effektív megnyilvánulása a hatályos Munka Törvénykönyve 96. \(1) bekezdése, amely kategorikusan kijelenti: „A munkaidő-beosztás szabályait (munkarend) a munkáltató állapítja meg.” (2012. évi I. törvény a munka törvénykönyvéről)

Munkajogi szabályozásunk ennek megfelelően a munkarend meghatározásánál a munkavállalói oldal számára főszabály szerint még csak véleményezési, észrevételezési jogot sem biztosít, mindez egy egyenrangú felek között létrejött szerződéses jogviszonyban meglehetősen atipikusnak tekinthetô és a hatalmasság legerőteljesebb megnyilvánulása a munkajog terén.

A kódex egyértelmúen azonos tartalommal ruházza fel a munkarend és a munkaidő-beosztás kifejezéseket, quasi azokat egymás szinonimájának tekinti. Nem minden szerző ért ezzel a jogalkotói szemlélettel egyet, Hovánszky Arnold szerint a munkarend és a munkaidő-beosztás egymásnak nem szinonimái, hanem önálló, sajátos tartalommal bírnak, a munkarend a rendes munkaidőben történő munkavégzés általános szabályait, a munkaidő-beosztás pedig a rendes vagy rendkívüli munkaidőben történő munkavégzés - az idókeret és annak egyes napjai tekintetében történó - további konkretizálását jelenti. (Hovánszky, 2001) Hovánszky megközelítését ugyanakkor nem tartja elfogadhatónak a Radnay József - Hartay Győző szerzőpáros, akik a klasszikus megközelítés hívei. (Radnay - Hartay, 2001, p. 47-48)

Álláspontunk szerint a munkarend és a munkaidő-beosztás ténylegesen nem egymás szinonimái, hanem önálló, bár természetesen rokon fogalmak, amelyek közül a munkarend egy tágabb meghatározás, amely hosszabb távon és általánosabban vonja meg az időbeli kereteket a munkavállaló számára, lényegesen 
Debreceni Jogi Múhely 2021. (XVIII.) 1-2.

Debreceni Egyetem, Állam- és Jogtudományi Kar, Debrecen

(University of Debrecen, Faculty of Law, Debrecen)

DOI 10.24169/DJM/2021/1-2/6

szélesebb értelmezési tartománnyal bírva, míg a munkaidő-beosztás ezen a munkarenden belül vagy éppen a korábban meghatározott munkarendnek az egyoldalú módosításával létrejött, általában rövidebb távú, még könnyebben módosítható munkáltatói utasítás.

A rendkívüli munkaidővel kapcsolatos szabályok - Munka Törvénykönyve 107 - 109. SS (2012. évi I. törvény a munka törvénykönyvéről) - hasonlóképpen teljes mértékig a munkáltató döntésére bízzák annak elrendelését és majdnem teljes egészében időpontját, időtartamát is, a munkavállaló egyedül azt kérheti, hogy a rendkívüli munkaidőt írásban rendelje el munkáltatója.

Tény, hogy a Munka Törvénykönyve 93. \(1) bekezdése értelmében a munkaidőkeret meghatározásánál is egyértelmúen a munkáltató hatalmassági pozíciója érvényesül, hiszen a munkaidőkeretre történő áttérés és - a törvény által meghatározott kereteken belül - a munkaidőkeret konkrét alkalmazási módja is a munkáltató diszkrecionális döntési jogkörébe tartozik. (2012. évi I. törvény a munka törvénykönyvéről)

A munkarend meghatározása során általános a munkáltató egyoldalú döntési pozíciója, amit a Munka Törvénykönyve 51. \-a kategorikusan a munkáltató diszkrecionális jogkörébe helyez. Figyelemmel arra, hogy a munkáltató kötelezettségi körébe tartozik a Munka Törvénykönyve 51. \$-a értelmében a munkavégzéshez szükséges feltételek biztosítása, a munka megszervezése, szükségszerú, hogy ennek a szervezőmunkának az időtényező meghatározása is elemét képezi. (2012. évi I. törvény a munka törvénykönyvéről)

Megoldásként szolgálhat annak a modellnek a paralel alkalmazása, ami Guy Davidov neves izraeli jogtudós szerzőtársával, Edo Eshet jogtudóssal leírt: „esettanulmányt ad egy új modellről, amelyet Izraelben fogadtak el bizonyos kollektív megállapodások útján. Ebben a modellben egy részletesen kidolgozott folyamatot kell követni annak biztosítása érdekében, hogy az elbocsátások nem véletlenszerúen történnek, de végeredményben a döntés kizárólag a munkáltató kezében van. Átbeszéljük a modellel kapcsolatos eddigi tapasztalatainkat, és megnézzük, hogy biztosít-e az kiegyensúlyozott megoldást a munkavállalók, dolgozók, és egészében véve a társadalom részére." (Davidov - Eshet, 2015, p. 1)

Véleményünk szerint ez a megoldás az adott témakör jogalkotásának megfeleló eleme lehetne, tehát ahol a munkavállalók érdekeiket érvényesíthetnék, egyeztetést kezdeményezhetnének, bár a végső döntés a munka megszervezőjét, a munkáltatót illetné. Ez a modell kiválóan felhasználható lenne a munkarend kialakításával kapcsolatban is és nagyban növelné a dolgozók komfortérzetét és így lojalitását.

Elvben a munkáltató a munkarend vagy munkaidő-beosztás meghatározásával nem hozhatná hátrányos helyzetbe a munkavállalókat, ugyanez semmiképpen sem mondható el feltétlenül a rendkívüli munkaidő elrendelésérôl, amely aktus ugyanakkor legalább mindenképpen jelentős többlet bevételi forrást jelent a munkavállalók számára, így kényelmetlensége és fárasztó mivolta ellenére általában kifejezetten népszerúnek tekinthető.

Mindezzel ellentétben a munkaidőkeret bevezetése alapjaiban is csak a munkáltató számára lehet kedvező. Amint a Nacsa Beáta - Seres Antal szerzőpáros rávilágít: „A gazdasági tevékenység csúcsidőszaka, amely az éves munkaidô-keret alkalmazása nélkül a rendkívüli munkavégzés esetén járó pótléknak (a túlmunka pótléknak) növekedéséhez vezetne, az éves munkaidő-keret alkalmazása esetén is többletmunkát igényel ugyan, de ezt a vállalat úgy kompenzálja, hogy a gazdasági tevékenység visszaesése idején adja ki a dolgozók pihenőidejét, tehát a csúcsidőszakon kívül kevesebbet kell dolgozniuk havi átlagban. A túlmunka pótlék tehát munkaidő-keret alkalmazásakor minimálisra csökken vagy megszűnik.

A munkaidő-keretek, és azon belül az éves keret két legnagyobb előnye a vállalatok részére, hogy

- csökken a bérköltség, mert megtakarítják a túlmunka pótlékot,

- megtakarítják annak költségét, hogy szezonális alkalmi dolgozókat vegyenek fel, majd utóbb munkaviszonyukat megszüntessék." (Nacsa - Seres, 2003, p. 3)

A hatalmasság alkalmazása a munkajog területén, ahol eleve a kiszolgáltatottabb fél kedvezótlenebb helyzetét rontja ez a megoldás, mindenképpen kétséges és reformra szorul a fent írtak szellemében. Az ilyen erőteljes megnyilvánulás, amely kizárólag a munkáltató érdekét szolgálja, nem látszik a munkajogi alapelvekkel és jogág szellemiségével összeegyeztethetőnek. Változatlan a véleményünk, miszerint a munkavállalói oldalnak is szükséges áldozatokat hozni a gazdasági előnyök érdekében, ez a szabályozási elem azonban kizárólag a 
Debreceni Jogi Múhely 2021. (XVIII.) 1-2.

Debreceni Egyetem, Állam- és Jogtudományi Kar, Debrecen

(University of Debrecen, Faculty of Law, Debrecen)

DOI 10.24169/DJM/2021/1-2/6

munkavállalói oldal számára hordoz terheket, míg előnyeit a munkavállalói oldal élvezi. Helyesebb lenne, ha a gazdasági tevékenység csúcsidőszakából a munkavállalói oldal is előnyöket élvezhetne.

A munkaidőkeret nem mást eredményez a munkavállalók számára, minthogy

- egyes időszakokban „éjjel-nappal” dolgozhatnak, amiért cserébe

- más időszakokban tétlenségre vannak kárhoztatva, miközben

- mindezért nem részesülnek többletjövedelemben.

Meglepő lehet, de a „rabszolgatörvénynek” csúfolt, a Munka Törvénykönyve vonatkozó paragrafusait módosító 2018. évi CXVI. törvény (2018. évi CXVI. törvény) rendelkezései kifejezetten munkavállalóbarátnak tekinthetôek az eredeti szabályokhoz képest, hiszen „400 óra túlórát rendelhet el a munkáltató egy naptári évben, feltéve, hogy a munkavállaló és a munkáltató megállapodnak ebben”, illetve ,a munkaidőkeret hossza 36 hónapra emelhető, ha kollektív szerződés ezt megengedi.” (Evershed, é. n.)

A Munka Törvénykönyve szerinti alap túlóra keret alkalmazásához, illetve a munkaidőkeret alapján történő múködésre történő átálláshoz ugyanis semmilyen hozzájárulás nem szükséges, míg a módosítást jelentő növekményekhez legalább szükséges a munkavállaló, illetve a szakszervezet hozzájárulása.

Összefoglalva a fentieket: a hatalmasság munkajogi szerepvállalásának kulcsterületét jelentik a munkaidôvel kapcsolatos rendelkezések, mindennapos körülmények között is a munkarend, illetve munkaidő-beosztás meghatározása során, illetve a munkaidőkeret alkalmazása terén, míg a pandémia okozta válsághelyzet az így kialakulható, munkavállalók számára potenciálisan veszélyt vagy problémát jelentő jogi szituációk száma élesen növekszik.

A hazai munkajogi szabályozás a fenti, meglehetősen kiszolgáltatott munkavállalói helyzet ellenére természetesen szab határokat az esetleges munkáltatói önkény előtt. Az érintett jogszabályhelyek mindössze részletszabályokkal húznak meg bizonyos kereteket, ezek a korlátok inkább alaptörvényi, illetve munkajogi alapelvi szinten kereshetőek meg.

Az Alaptörvény Szabadság és Felelősség fejezetének XVII. cikkében elsősorban együttműködési kötelezettséget ír elő munkavállalók és munkáltatók között, ugyanakkor rögzíti, hogy minden munkavállalónak joga van az egészségét, biztonságát és méltóságát tiszteletben tartó munkafeltételekhez, valamint a napi és heti pihenőidőhöz, valamint az éves fizetett szabadsághoz. (Magyarország Alaptörvénye (2011. április 25.))

Ezek az Alaptörvényben meghatározott jogok, illetve kötelezettségek minden kétséget kizáróan behatárolják a munkáltatói hatalmasság korlátlan érvényesülését is, a Munka Törvénykönyve 97. \(1) bekezdésében visszautal arra, hogy a munkáltató az egészséges és biztonságos munkavégzés követelményére, valamint a munka jellegére figyelemmel alkothatja meg a munkarendet. (2012. évi I. törvény a munka törvénykönyvéről)

Természetesen a hatalmasság alkalmazása a munkaidővel kapcsolatos jogterületeken sem lehet visszaélésszerű és nem sértheti az egyenlő bánásmóddal kapcsolatos jogalkotói elvárásokat. Az egyenlő bánásmódról és az esélyegyenlőség előmozdításáról szóló 2003. évi CXXV. törvény, mint lex specialis adott esetben nem derogálja, hanem éppenséggel kifejezetten megerősíti a lex generalis-t, munkajogi kódexünk vonatkozó rendelkezéseinek alkalmazását.

A Munka Törvénykönyve 7. \-a joggal való visszaélésnek minősíti mások zaklatását. (2012. évi I. törvény a munka törvénykönyvéről) Az egyenlő bánásmódról és az esélyegyenlőség előmozdításáról szóló törvény ugyancsak 7. \-a (1) bekezdésében ugyanakkor ekként rendelkezik:

„Az egyenlő bánásmód követelményének megsértését jelenti - különösen a III. fejezetben meghatározottak szerint - a közvetlen hátrányos megkülönböztetés, a közvetett hátrányos megkülönböztetés, a zaklatás, a jogellenes elkülönítés, a megtorlás, valamint az ezekre adott utasítás.” (2003. évi CXXV. törvény)

Az egyenlő bánásmódról és az esélyegyenlőség előmozdításáról szóló törvény 10. \(1) bekezdése pedig bezárja a kört: Zaklatásnak minősül az emberi méltóságot sértő, szexuális vagy egyéb természetű magatartás. (2003. évi CXXV. törvény) 
Debreceni Jogi Múhely 2021. (XVIII.) 1-2.

Debreceni Egyetem, Állam- és Jogtudományi Kar, Debrecen

(University of Debrecen, Faculty of Law, Debrecen)

DOI 10.24169/DJM/2021/1-2/6

Értelemszerúen a joggal való visszaélés tilalmának megfogalmazása és a zaklatás joggal való visszaéléssé minősítése kiterjed a munkaidôvel kapcsolatos egyoldalú munkáltatói intézkedések visszaélésszerú gyakorlásának tilalmára is. Nyilvánvalóan nem alkalmazhat olyan akár egyéni, akár a munkavállalók egy csoportjára vonatkozó munkarendet a munkáltató, amely zaklatásnak minősülne, hátrányos megkülönböztetést valósítana meg, esetleg megtorlást jelentene a munkavállalók egyéb jogaikhoz való ragaszkodása miatt.

Ilyen eset volt a Szolnoki Megyei Kórháznál bevezetni tervezett 12 órás napi munkaidő jogszerűségének kérdése, ahol a munkáltató kétségtelenül a Kórház sebészorvosai által az ügyeleti idő teljes munkaidőként történő elismerése és teljes összegú munkadíjazása iránt sikerrel indított perben meghozott ítélet „megtorlásául” próbálta az orvosokat napi 12 órás múszakban foglalkoztatni. (Prugberger, 2006, p. 52)

Adott esetben ágazati jogszabályok is segítséget nyújtanak a munkavállalók jogos érdekeinek védelmében, a citált esetben például az Egészségügyi Törvény rendelkezései is hozzájárultak a munkáltatói szándék visszavonultatásához. (1997. évi CLIV. törvény)

Sok esetben egyébként a gazdasági megfontolás is határokat szabhat a túlzóan terhes munkarendet vagy rendkívüli munkavégzést elrendelő munkáltatói döntéseknek, amelyek lehetnek gazdaságilag rövid távon érthetőek, elfogadhatónak azonban nem nevezhetőek és hosszú távon egész biztosan nem kifizetôdőek az elsősorban az értékes munkaerôt érintő növekvő fluktuáció és a munkavállalói lojalitás és komfortérzés csökkenése folytán.

Prugberger Tamás megállapítása szerint „A rendkívüli munkavégzés esetei közül neuralgikusnak számít még a készenlét és az ügyelet. A készenlétet - ami azt jelenti, hogy a munkavállaló a munkahelyén kívül bárhol tartózkodhat, azonban munkába állás végett a munkáltató által elérhetőnek kell lennie - sem az európai munkajog, illetőleg az európai bírósági ítélkezési gyakorlat, sem a tagállamok munkajoga nem tartja munkaidőnek, és ezért nem is díjazza. ezzel szemben az ügyeletet rendkívüli munkaidőnek, illetve munkavégzésnek tekintik a nyugat-európai államok munkajogi szabályai... ... kimondva azt is, hogy az ügyeletre is a rendes munkabér jár. (Prugberger, 2017, p. 34)

Az a tény, ha a munkáltató a terhesebb munkarendet vagy az elrendelt rendkívüli munkavégzést köteles arányosan honorálni a munkavállaló számára, sok esetben elveszi a munkáltató kedvét a munkavállalók túlzott terhelésétől, nem lehet akadálya a terheket vállaló munkavállalók megfelelő javadalmazásának. Az egészségügyben megszokott az ügyelet és a készenlét intézménye a munkavállalók számára, tipikusan szívesen is vállalják ezeket a feladatokat (vannak „ügyelethalmozók” is, akiket már korlátozni kell ilyen szándékaikban), azonban ezekben a kifejezetten nagy felelősséggel járó munkakörökben is nagyon fontos az igazságos juttatás. Ezeknek a céloknak a megvalósításához szükséges a munkajogi jogalkotás megfeleló közrehatása, így egy komplex újra szabályozásnak ez is kiemelkedően fontos eleme lehet.

\section{A kötetlen munkaidő}

A kivétel erősíti a szabályt szólásunk a jog területére is igaz, a Munka Törvénykönyve is ismer kivételeket, akár kógens szabályai esetében is. A hatalmasságnak a munkarend meghatározásában történő érvényesülése alól is van kivétel, ez pedig a Munka Törvénykönyve 96. \$ (2) - (3) bekezdéseiben foglalt kötetlen munkarend intézménye. (2012.évi I. törvény a munka törvénykönyvéről)

Zárójelben jegyezzük meg, hogy a kötetlen munkarend elrendelése vagy megengedése is a munkáltató diszkrecionális jogkörébe tartozik, ennek megfelelóen természetesen visszavonása vagy megszüntetése is általában a munkáltató kizárólagos döntésétől függ.

A Munka Törvénykönyve ugyanakkor néhány esetben kötelezővé (a vezető munkarendje esetében) vagy alapesetté (távmunkavégzés, bedolgozói munkaviszony) nyilvánítja a kötetlen munkarendet, bár utóbbi esetekben a felek megállapodása attól eltérhet. A munkakör megosztása esetén a törvény szintén a kötetlen munkarendre vonatkozó szabályokat rendeli megfelelóen alkalmazni. (2012.évi I. törvény a munka törvénykönyvéről)

A kötetlen munkarend mindenesetre azt jelenti, hogy a munkáltató lemond a munkarend meghatározásával kapcsolatos privilégiumáról, sőt - előre meghatározott kereteken belül - átadja ezt a privilégiumot a 
Debreceni Jogi Múhely 2021. (XVIII.) 1-2.

Debreceni Egyetem, Állam- és Jogtudományi Kar, Debrecen

(University of Debrecen, Faculty of Law, Debrecen)

DOI 10.24169/DJM/2021/1-2/6

munkavállaló számára. Természetesen - mindennek ára van - a kötetlen munkarend árnyoldala a munkavégzés önálló megszervezésének feladata a munkavállaló számára, így a kötetlen munkarend kellemes mivolta óhatatlanul együtt jár a feladatok növekedésével, a felelősség súlyosbodásával és azzal, hogy a munkavállaló olyan a munka előrehaladását gátló körülményekért is felelős lehet, amelyek egyébként messzemenően nem az Ő érdekkörébe esnének.

A kötetlen munkarend szektorspecifikus jelenség, nem jellemző, amennyiben az egyént figyelmen kívül hagyó, olyan ágazatról beszélünk, ahol a legelterjedtebbek az antiszociális munkarendek: a bányászatban, textiliparban, gépiparban, egészségügyi és szociális ellátásban, míg a kötetlen munkarend egyre elterjedtebb a pénzügyi szektor, az ingatlanügyletek-bérbeadás-gazdasági tevékenységet segítő szolgáltatások, valamint az egyéb szolgáltatások terén. (Frey, 2000)

Friedrich Herzberg munkavállalói elégedettség koncepciója szerint „A szervezet elégedett alkalmazottai önállók, és motiváltak a szervezeti célok elérésében. Az általa vizsgált és leírt higiéniai tényezők növelik az elégedettséget, de a megfelelő motivációhoz szükség van a munkavégzés rugalmassá tételére, a magas színvonalú felügyelet bevezetésére, a munkavégzés biztonságára vonatkozó hatékony intézkedésekre, a karrierfejlesztési lehetőségekre, a közös felelősségvállalásra. A munkavégzés rugalmassá tétele jelentősen előmozdítja a szervezeti tevékenység sikerét és szükség szerint motiválja a dolgozókat.” (Knoll-Csete, 2020, p. 2)

Nem vitásan előny az is, hogy a kötetlen munkarend számtalan feladattól mentesíti a munkáltatót, amint a Sipka - Zaccaria szerzőpáros megállapítja, „egy tevékenység munkaidőnek minősítése gyakran jelent nehézséget a feleknek, másik oldalról pedig napjaink munkaerőpiacának egyik legalapvetőbb elvárása a munkáltatókkal szemben a rugalmas, dinamikus foglalkoztatási struktúra kialakítása és fejlesztése, amelyben komoly szerepet játszik munkaidő és annak beosztása, akár úgy, mint flexibilis munkaviszonyok alapja, akár, mint klasszikus értelemben vett foglalkoztatáspolitikai eszköz. (Sipka - Zaccaria, 2016, p. 449-450)

A számtalan előny mellett a kötetlen munkarend értelemszerúen kockázatokat is rejt a munkáltató számára, hiszen a vállalkozás kitűzött gazdasági céljainak megvalósulását is megakadályozhatják alkalmatlan vagy felelőtlen kötetlen munkarendben dolgozó munkavállalók, ugyanakkor viszont az sem vonható kétségbe, hogy nem minden munkavállaló számára kellemes állapot ez - sokan szeretnek inkább katonás rendben, de kisebb feladat- és főleg felelősségkvótával dolgozni.

A kötetlen munkarend speciális esete lehet a besegítő, azaz más háztartásában végzett háztartási munka, ahol a viszonyok természetükből adódóan nem feltétlenül átláthatóak és tisztázottak, esetleg akár nem is teljesen legálisak, ugyanakkor ebből is származóan nyilvánvalóan rendkívül rugalmasak lehetnek, azonban a munkavállaló kiszolgáltatottsága ezért is rendkívüli mértékú. (Kulinyi, 2016)

Összességében a kötetlen munkaidôt - bár kétségkívül rendkívül előnyös lehet a munkavállaló számára is -, nem látjuk a hatalmasság erős érvényesülésével szembeni alkalmas megoldásnak, az csak a megoldás egyik részeleme lehet.

\section{Jogharmonizációs feladatok és nemzetközi megoldások}

A munkavállalói oldal pozíciójának megerósítése komoly jogalkotói feladatot jelent. Ennek során egyes megoldások adottak, hiszen Magyarországot - az Európai Unió többi tagállamával egyező módon jogharmonizációs kötelezettség terheli az Európai Unió joga vonatkozásában, további feladatokat azonban a hazai jogtudománynak saját kútfóből kell megoldania, minek során mindenkor érdemes külföldi - akár Európai Unión kívüli - jogtudósok munkásságát áttekintenünk. Hazai jogalkotásunk és jogalkalmazásunk számára nagy jelentőségű - Európai Uniós tagságunk és jogharmonizációs kötelezettségünk folytán az Európai Unió jogalkotása.

„Az Európai Unió az eltelt évtizedekben folyamatosan intenzíven foglalkozott a munkaidővel kapcsolatos jogkérdésekkel, ennek következménye, hogy az említett, a munkaidő-szervezés egyes szempontjairól szóló 2003/88/EK irányelv már a harmadik irányelv a jogterületen." (Prugberger, 2017, p. 31) Prugberger Tamás elemzésében arra is kitér, hogy a későbbi irányelvek nem helyezték hatályon kívül teljesen a korábbi irányelveket, így a szabályozás meglehetósen összetettnek, esetleg nehezen követhetőnek is bizonyul 
Debreceni Jogi Múhely 2021. (XVIII.) 1-2.

Debreceni Egyetem, Állam- és Jogtudományi Kar, Debrecen

(University of Debrecen, Faculty of Law, Debrecen)

DOI 10.24169/DJM/2021/1-2/6

megítélésünk szerint.

A 2003/88/EK irányelv 2. cikk 1. pontjának munkaidő meghatározása az alábbi: „Munkaidő: az az idôtartam, amely alatt a munkavállaló dolgozik, a munkáltató rendelkezésére áll, és tevékenységét vagy feladatát végzi a nemzeti jogszabályoknak és/vagy gyakorlatnak megfelelően”. (Az Európai Parlament és a Tanács 2003/88/EK Irányelve)

Az Európai Unió joggyakorlata, különösen az Európai Bíróság jogalakító eseti döntései útján igyekszik a munkavállalói akaratérvényesítés lehetőségeit növelni. „A külföldi befektetők érdeklődésének középpontjában áll még az is, hogy a munkaidő, a pihenőidő, a túlóra, a túlmunka- és a teljesítménybérezés paramétereinek, továbbá a szabadságkiadás időpontjának, azaz általában a vállalati-üzemi munkarend kialakításának a meghatározásában milyen beleszólási joga van a munkavállalói oldalnak." (Prugberger Nádas, 2014) - a Prugberger - Nádas szerzőpáros kijelentésének igazságtartalma nehezen lenne kétségbe vonható, miként az a tény sem, hogy „a legtöbb nyugat-európai államban ugyanis a munkaidőt a munkáltató az üzemi tanáccsal egyetértésben, vele közösen elkészített munkarendben állapítja meg. A magyar szabályozás azért is hátrányos a munkavállalókra, mert a munkáltatók többsége - miként erről korábban már szó esett - mindent megtesz annak érdekében, hogy ne kelljen kollektív szerződést kötnie a munkavállalói érdekképviseletekkel.” (Prugberger - Nádas, 2014, p. 257) A szerzőpáros megállapításai hét év elteltével is érvényesek és alátámasztják a fenti gondolatokat, miszerint a jogharmonizációs kötelezettségen túl idôszerú és szükséges lenne egy teljeskörüen kidolgozott hazai szabályozása a munkaidôvel kapcsolatos munkajogi joganyagnak, amely a hatalmasság helyett a konszenzus alkalmazását helyezné előtérbe.

Az Európai Unió jogának részletes elemzése természetesen most nem feladatunk, ennek ellenére rövid betekintésünkkel is megállapíthatjuk, hogy a hatalmasság nagyfokú érvényesülése és makacs fennmaradása a munkarend, a rendkívüli munkavégzés, illetve a munkaidőkeret elrendelése terén nem elkerülhetetlen sajátossága a munkajogi szabályozásnak - ezzel ellentétben a szabályozás merevségének fellazítása a jogfejlődés útja, amely a munkavállalói felelősségvállalás és elégedettség növelése útján jelentős eszköze lehetne a termelékenység, a gazdasági növekedés és a hatékonyság növelésének, egyben csökkenthetné a fluktuációt és segíthetné az értékes munkaerő megôrzését.

A célzott módosítások kiforrottsága érdekében - álláspontunk megerôsítése, illetve jó gyakorlatok felkutatása céljából - érdemes az Európai Unión kívüli jogtudósok véleményét is megismernünk.

A jogtudomány külföldi mestereinek szakmai eredményeit vizsgálva álláspontunk csak megerősödhet. Guy Davidov munkássága révén részint az izraeli, részint az angolszász jogrendbe pillanthatunk bele és megismerhetjük a munkaidő vizsgálata tekintetében is relevanciával bíró megállapítását: 'A „biztos munkahelyet" általában a munkavállalót megillető jogként értelmezzük arra vonatkozóan, hogy a munkavállaló jogos indok nélkül nem kerül elbocsátásra.' (Davidov - Eshet, 2015, p. 1) Simon Deakin megállapítása gazdasági megközelítésben, de mindenképpen paralel, miszerint „A munkajog gazdasági hatásaival kapcsolatban elméleti, historikus és kvantitatív tekintetben végzett empirikus kutatások áttekintésével arra lehet következtetni, hogy a munkavállalót védő munkaügyi szabályozásnak tisztán pozitív eredményei vannak a fejlődés és növekedés tekintetében.” (Deakin, 2016, Abstract)

Mindkét megközelítés a fent írt gondolatot erősíti meg: a hatalmasság lazítása előnyére válna a munkavállalók biztonságérzetének és így lojalitásának, de a hatékonyságnak és termelékenységnek is. Guy Davidov részletesen ír a „New Employment Practices”-ről, tehát az újszerű foglalkoztatási módokról, érzékeltetve, hogy a kötetlen munkarenddel kapcsolatos felvetéseink minden jogrendszerben lehetőséget teremtenek és egyben problémákat vetnek fel. (Davidov, 2010, p. 2)

Európa szívében kutatva Manfred Weiss munkáit áttekintve állapíthatjuk meg, hogy az Európai Unió, illetve az Európai Bíróság jogalkotási - jogalkalmazási törekvései a megfelelő jogtudományi háttérrel is rendelkeznek, de azt is, hogy a munkajog hatalmassági rendszerének fellazítása sok bizonytalansággal és még több feladattal is jár. Manfred Weiss megállapítása szerint. „A munkajog jövőjéről beszélni kicsit olyan, mintha az időjárásról beszélnénk: könnyen előfordulhat, hogy a jövőbeli fejlemények megcáfolják az embert. Így aztán tisztában kell lennünk azzal, hogy ez nagyrészt spekuláció, és az elképzeléseket kellő óvatosság és mértékletesség mentén kell kialakítani." (Weiss, é. n., p. 1)

A felvetett problémák általánosságát erősíti Kahn-Treund Labour and the law címú műve is: „A kollektív 
Debreceni Jogi Múhely 2021. (XVIII.) 1-2.

Debreceni Egyetem, Állam- és Jogtudományi Kar, Debrecen

(University of Debrecen, Faculty of Law, Debrecen)

DOI 10.24169/DJM/2021/1-2/6

kereskedelmi megállapodás megkötését követően, egyedi munkaerőfelvételek útján kell meghatározni annak kedvezményezettjeit. A munkáltató - amennyiben azt nem maga a kollektív megállapodás korlátozza szabadon választhatja ki, hogy kit kíván alkalmazni, illetve elbocsátani. A foglalkoztatás feltételei azonban már adottak. A munkaerőfelvételen kívül nem sok minden maradt, ami még megállapodás tárgyát képezi..." (Kahn - Freund's, 1983, p. 157)

\section{Konklúzió, összefoglalás}

A kivétel erősíti szabályt - említettük a fentiekben s látható, hogy ez többszörösen is így igaz. A munkajogra alapvetően nem jellemző a hatalmasság érvényesülése, így a munkaidôvel kapcsolatos szabályok - amelyek túlnyomórészt a munkáltató diszkrecionális jogkörébe tartoznak - ilyen tekintetben kivételnek számítanak. A kötetlen munkarend lehetôsége ugyanakkor a munkaidővel kapcsolatos hatalmasság - fölény alól jelent kivételt, így tulajdonképpen a kivétel kivétele.

Ez a bonyolultnak tûnő rendszer mindazonáltal lehetôséget ad arra, hogy meggyőződjünk arról, hogy építő jellegű-e a hatalmasság érvényesülése a munkajogi szabályozásban vagy célszerúbb lenne egy kiegyenlítettebb, ugyanakkor fenntarthatóbb rendszer alkalmazása, akár a Guy Davidov által javasolt munkáltatói ultima ratio megoldásával.

Megjegyezve, hogy a fent is említettek szerint a kötetlen munkarend is rejt magában veszélyeket, álláspontunk szerint hatékonyabb és szociálisabb lenne egy konszenzusos rendszer kialakítása, amellyel nem mellesleg Európai Uniós jogharmonizációs kötelezettségeinknek is eleget tennénk.

Természetesen nem tekinthető könnyű feladatnak a jelenlegi, hatalmasságon alapuló munkarenddel kapcsolatos szabályozás felváltása egy konszenzuson alapuló rendszerrel. A hatalmasság erőteljes érvényesülésének nem csak racionális (munkaszervezéssel, a munkavégzéshez szükséges feltételek biztosításával kapcsolatos) indokai vannak, hanem a hagyomány, a beidegződés, a munkáltatói, de egyben a munkavállalói oldal vonatkozó álláspontjának megszilárdulása a jelen status quo tekintetében - ez mind ellene szól egy szociális és egyben hatékony, a hatalmasságot háttérbe szorító új szabályozás megalkotásának.

A változás ugyanakkor véleményünk szerint nem mellőzhető. A munkarend meghatározásánál a munkavállalói oldal véleményének érdemi figyelembevétele túlnyomó részben - nem kétségesen - alkalmas a hatékonyság növelésére, a magasabb hatékonyság pedig mindkét oldalnak érdeke, hiszen nem csak a profitot növeli, de legalkalmasabb eszköze a magasabb bérek, a stabilabb munkahelyek és a jobb munkakörülmények elérésének. A szociálisabb megközelítés ugyanakkor nélkülözhetetlen a munkavállalók közérzete javítása, elhivatottságának és lojalitásának erősítése terén.

Csak egyet tudunk érteni az elmúlt évek jogharmonizációját értékeló összefoglaló megállapításával, miszerint: „A munkaidő-szervezésről szóló irányelv elfogadása hatást gyakorolt a munkaidővel kapcsolatos előírásokra azon tagállamokban, amelyek 2004 óta csatlakoztak az Unióhoz: ezen országokban egészen 2011-ig csökkent a rendes munkaidő. A kollektív tárgyalás mindazonáltal még mindig igen csekély szerepet játszik ezen országok többségében, ahol a rendes munkaidő általában hosszabb, mint a módosítható rendelkezésen alapuló vagy a tárgyalásos munkaidő-megállapítási rendszert alkalmazó országokban.” (Európai Alapítvány az Élet- és Munkakörülmények Javításáért: Munkaidővel kapcsolatos fejlemények a 21. században: a munkaidô és szabályozása az EU-ban)

Jogalkotásunk s így munkajogi jogalkotásunk előtt számos feladat áll társadalmi - gazdasági problémák megoldásának elősegitése, illetve a jogharmonizációs kötelezettségek teljesítése érdekében - a fenti megállapítások álláspontunk szerint alátámasztják, hogy a munkaidő szabályozásának liberálisabbá tétele a jogalkotásunk előtt álló legfontosabb feladatok közé tartozik.

\section{Felhasznált irodalom}

BERKE Gyula (2020) Munkajog veszélyhelyzetben, In: PÁL Lajos - PETROVICS Zoltán (szerk.): A XVII. Magyar Munkajogi Konferencia szerkesztett előadásai, Wolters Kluwer Hungary Kft., Budapest, 21-41. https://www.wolterskluwer.com/hu-hu/solutions/munkajogi-konferencia (letöltve: 2021. 01. 17.) 
Debreceni Jogi Múhely 2021. (XVIII.) 1-2.

Debreceni Egyetem, Állam- és Jogtudományi Kar, Debrecen

(University of Debrecen, Faculty of Law, Debrecen)

DOI 10.24169/DJM/2021/1-2/6

BODÓ László (2011) A polgári jog és a munkajog összehasonlítása az alapelvek tükrében, Debreceni Jogi Múhely

http://www.debrecenijogimuhely.hu/archivum/4_2012/a polgari_jog_es_a munkajog_osszehasonlitasa _az_alapelvek_tukreben/(letöltve: 2021. 01. 17.) https://doi.org/10.24169/DJM/2012/4/2

DAVIDOV Guy \& ESHET Edo (2015) Intermediate Approaches to Unfair Dismissal Protection Published in the 44 Industrial Law Journal 167, 1. https://academic.oup.com/ili/article-abstract/44/2/167/652591 (letöltve: 2021. 01. 16.) https://doi.org/10.1093/indlaw/dwv007

DAVIDOV Guy (2010) The Enforcement Crisis in Labour Law and the Fallacy of Voluntarist Solutions, International Journal of Comparative Labour Law and Industrial Relations, Vol. 26, 2. https://ssrn.com/abstract $=1549699$ (letöltve: 2021 . 01. 15.)

DEAKIN Simon (2016) The contribution of labour law to economic development and growth Centre for Business Research, University of Cambridge Working Paper No. 478, 2016. https://www.cbr.cam.ac.uk/fileadmin/user upload/centre-for-business-research/downloads/workingpapers/wp478.pdf (letöltve: 2021. 01. 15.)

Európai Alapítvány az Élet- és Munkakörülmények Javításáért: Munkaidővel kapcsolatos fejlemények a 21. században: a munkaidó és szabályozása az EU-ban https://europa.eu/european-union/abouteu/agencies/eurofound_hu (letöltve: 2021. 01. 18.)

EVERSHEDS Sutherland: Latest news https://www.evershedssutherland.com/global/en/what/publications/shownews.page (letöltve: 2021. 01. 18.)

FODOR T. Gábor (2016) A Munka Törvénykönyve munka- és pihenőidő szabályozásának uniós jogi megfelelőségéről, In: Magyar Munkajog E-folyóirat, $2 . \quad$ sz., 21. http://hllj.hu/letolt/2016_2/M_02_Fodor_hlli_2016_2.pdf(letöltve: 2021. 01. 19.)

FODOR T. Gábor (2019) Még egyszer a munkaidős szabályok uniós meg(nem)feleléséről - az Európai Unió Bíróságának a Syndicat des cadres de la sécurité intérieure ügyben hozott ítélete fényében, Munkajog, 4. sz. https://munkajogilap.hu/meg-egyszer-a-munkaidos-szabalyok-unios-megnemfeleleserol-az-europaiunio-birosaganak-a-syndicat-des-cadres-de-la-securite-interieure-ugyben-hozott-itelete-fenyeben/ (letöltve: 2021. 01. 19.)

FREY Mária (2000) A munkaidőrendszerek rugalmassá válása, Közgazdasági Szemle, XLVII. évf., december, 1008-1026. http://epa.oszk.hu/00000/00017/00066/pdf/frey.pdf(letöltve: 2021. 01. 18.)

HALMOS Szilvia - KÁRTYÁS Gábor (2019) A munkaerőhiány és feloldásának munkajogi eszközei egy empirikus vizsgálat tükrében, In: BANKÓ Zoltán - BERKE Gyula - PÁL Lajos - PETROVICS Zoltán (szerk.): Ünnepi tanulmányok Lőrincz György 70. születésnapja tiszteletére, HVG-ORAC Lap- és Könyvkiadó Kft., 152. https://munkajogilap.hu/download/unnepi-tanulmanyok-lorincz-gyorgy-70szuletesnapja-tiszteletere/(letöltve: 2021. 01. 17.)

HOVÁNSZKY Arnold (2001) A munkarend és a munkaidő-beosztás elhatárolása és definiálása I-II. rész jogszerűségének kérdése, In: Munkaügyi Szemle, 1-2. sz. https://www.munkaugyiszemle.hu/munkarendes-munkaido-beosztas-elhatarolasa-es-definialasa-i (letöltve: 2021. 01. 15.)

KAHN-FREUND'S (1983) Labour and the Law, Third edition, STEVENS \& SONS, London 157. https://socialsciences.exeter.ac.uk/media/universityofexeter/schoolofhumanitiesandsocialsciences/law/p

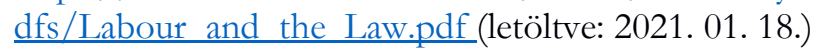

KÁRTYÁS Gábor (2020) XXI. század és munkajog: megőrizni vagy megreformálni? In: PÁL Lajos PETROVICS Zoltán (szerk.): A XVII. Magyar Munkajogi Konferencia szerkesztett előadásai Wolters Kluwer Hungary Kft. Budapest, 43. https://jogaszvilag.hu/szakma/kartyas-gabor-xxi-szazad-es-munkajogmegorizni-vagy-megreformalni/(letöltve: 2021. 01. 19.)

KISMÁRTON Kitti (é. n.) A nők munkaerô-piaci helyzete Magyarországon http://midra.unimiskolc.hu:80/?docId=18718 (letöltve: 2021. 01. 19.)

KISS György (2010) Alapjogok kollíziója a munkajogban, Pécs, 5-6. sz. 
Debreceni Jogi Múhely 2021. (XVIII.) 1-2.

Debreceni Egyetem, Állam- és Jogtudományi Kar, Debrecen

(University of Debrecen, Faculty of Law, Debrecen)

DOI 10.24169/DJM/2021/1-2/6

http://real.mtak.hu/25691/1/alapjogok kollizioja_a munkajogban.pdf(letöltve: 2021. 01. 18.)

KISS György (2020) Válság, közösség, szolidaritás - van-e (munka)joga a válságnak? Kézirat

KNOLL-CSETE Edit (2020) A rugalmas munkavégzés németországi szabályozása, In: Munkaügyi Szemle, június https://www.munkaugyiszemle.hu/rugalmas-munkavegzes-nemetorszagi-szabalyozasa (letöltve: 2021. 01. 18.)

KULINYI Márton (2016) A láthatatlan háztartási munka - fórumbeszélgetés, In: Munkaügyi Szemle, 4. sz. https://www.munkaugyiszemle.hu/lathatatlan-haztartasi-munka- $\%$ E2\% $\% 0 \%$-forumbeszelgetes (letöltve: 2021. 01. 18.)

Marx Karl (1955) A tôke, Szikra, Budapest https://mek.oszk.hu/04700/04724/04724.pdf (letöltve: 2021. 05. 28.)

NACSA Beáta - SERES Antal (2003) Az éves munkaidő-elszámolás, mint a munkaidő flexibilizációjának egyik eszköze, Magyar Tudományos Akadémia Közgazdaságtudományi Kutatóközpont, Budapest, 3. https://adoc.pub/az-eves-munkaid-elszamolas-mint-a-munkaid-flexibilizaciojana.html (letöltve: 2021. 01. 16.)

PÁL Lajos (2020) Munkajogi elvi kérdések: A foglalkoztatási és rendelkezésre állási kötelesség teljesítése a veszélyhelyzet tartama alatt, In: Glossa Iuridica VII. évf., Különszám, Jog és vírus, Károli Gáspár Református Egyetem Állam- és Jogtudományi Kar, Budapest

PÁL Lajos (2018) A munkaidővel kapcsolatos fogalmak (dogmatikai adalékok), In: PÁL LajosPETROVICS Zoltán (szerk.): Visegrád 15.0, Wolters Kluwer, Budapest, 104-129. https:// pallajos.files.wordpress.com/2019/04/a-munkaidc591vel-kapcsolatos-fogalmak.pdf _(letöltve: 2021. 01. 15.)

PRUGBERGER Tamás (2017) A munkaidő, a pihenőidő és a szabadság új hazai szabályozásának megítélése a munkavállalói érdekek szempontjából, In: Pro Futuro, $2 . \quad$ sz., 31-47. https://ojs.lib.unideb.hu/profuturo/article/view/4761/4494 (letöltve: 2021. 01. 15.) https://doi.org/10.26521/Profuturo/2017/2/4761

PRUGBERGER Tamás (2011) A munkaidő, a pihenő idő és a szabadság várható új magyar jogi szabályozásának kérdéséhez, In: Jogtudományi Közlöny, 11. sz., 539-549.

PRUGBERGER Tamás (2006) A Szolnoki Megyei Kórháznál bevezetni tervezett 12 órás napi munkaidő jogszerűségének kérdése. Munkaügyi Szemle. 1. sz., 52. https://www.munkaugyiszemle.hu/szolnokimegyei-korhaznal-bevezetni-tervezett-12-oras-napi-munkaido-jogszerusegenek-kerdese (letöltve: 2021. 01. 15.)

PRUGBERGER Tamás - NÁDAS György (2014) Európai és magyar összehasonlító munka- és közszolgálati jog, Wolters Kluwer Kft., Budapest, 2. sz., 43., 257.

RADNAY József (2004) A munkaidő és pihenőidő egyes kérdései, In: Gazdaság és Jog, 5. sz. 15-17.

RADNAY József - HARTAY Győző (2001) A munkarend és a munkaidő-beosztás egyes kérdéseihez, In: Munkaügyi Szemle, 6. sz., 47-48. https://www.munkaugyiszemle.hu/munkarend-es-munkaido-beosztasegyes-kerdeseihez (letöltve: 2021. 01. 18.)

SERES Antal (2014) Gazdasági szektorok, tevékenységek és a részmunkaidő alkalmazása közötti kapcsolat In: Munkaügyi Szemle, 4. sz., 58-67. https://www.munkaugyiszemle.hu/gazdasagi-szektoroktevekenysegek-es-reszmunkaido-alkalmazasa-kozotti-kapcsolat (letöltve: 2021. 01. 18.)

SERES Antal - BUDAI Balázs (2013) A részmunkaidő és a vállalati nagyság közötti kapcsolat egy hazai felmérés alapján, In: Munkaügyi Szemle, 3. sz., 72-77. https://www.munkaugyiszemle.hu/reszmunkaidoes-vallalati-nagysag-kozotti-kapcsolat-egy-hazai-felmeres-alapjan (letöltve: 2021. 01. 18.)

SIPKA Péter - ZACCARIA Márton Leó (2016) Dolgozik és pihen? A munkaidő fogalmának bővítése az Európai Unió Bíróságának újabb ítélete nyomán, tekintettel a magyar joggyakorlatra, In: Jogtudományi Közlöny, 9. sz., 449-457. 
Debreceni Jogi Múhely 2021. (XVIII.) 1-2.

Debreceni Egyetem, Állam- és Jogtudományi Kar, Debrecen

(University of Debrecen, Faculty of Law, Debrecen)

DOI 10.24169/DJM/2021/1-2/6

SMITH Adam (1977) Az erkölcsi érzelmek elmélete, In: Brit moralisták a XVIII. században, Gondolat, Budapest, 423-553

SMITH Adam (1959) A Nemzetek gazdagsága, E gazdagság természetének és okainak vizsgálata https://docplayer.hu/3159501-A-nemzetek-gazdagsaga.html (letöltve: 2021. 06. 01.)

SZENTES Tamás (2018) Marx politikai gazdaságtana, Avagy: marxista volt-e maga Marx? In: KÖZGAZDASÁG 2. sz. https://core.ac.uk/download/pdf/159129091.pdf (letöltve: 2021. 06. 01.) https://doi.org/10.14267/RETP2018.02.02

WEISS Manfred: The future of labour law in the context of global challenge https://www.ilera2015.com/dynamic/full/Manfred Weiss keynote.pdf(letöltve: 2021. 01. 15.)

ZACCARIA Márton Leó (2017) Szociálisan védett vagy gazdaságilag veszélyeztetett? Munkavállalói Alapjogok az Európai Unió Bíróságának joggyakorlatában, In: Állam- és Jogtudomány, LCIII. évfolyam 3. sz., 73-98.

ZACCARIA Márton Leó (2011) Diszkrimináció a diszkriminációban? Avagy a részmunkaidős foglalkoztatás és a nemi esélyegyenlőség összefüggései, Jogtudományi Közlöny, 1. sz., 62-68.

Jogszabályok:

47/2020. (III. 18.) Korm. rendelet a koronavírus világjárvány nemzetgazdaságot érintő hatásának enyhítése érdekében szükséges azonnali intézkedésekrôl http://njt.hu/cgi bin/njt doc.coi? docid=218577.380802 (letöltve: 2021. 02. 05.)

2018. évi CXVI. törvény a munkaidő-szervezéssel és a munkaerő-kölcsönzés minimális kölcsönzési dijával összefüggó egyes törvények módositásáról https://mkogy.jogtar.hu/jogszabaly?docid=A1800116.TV (letöltve: 2021. 02. 05.)

2012. évi I. törvény a munka törvénykönyvéről https://net.jogtar.hu/jogszabaly?docid=a1200001.tv (letöltve: 2021. 02. 05.)

Magyarország Alaptörvénye (2011. április 25.) https://net.jogtar.hu/jogszabaly?docid=a1100425.atv (letöltve: 2021. 01. 30.)

2003. évi CXXV. törvény az egyenlő bánásmódról és az esélyegyenlőség előmozdításáról https://mkogy.jogtar.hu/jogszabaly?docid=a0300125.TV (letöltve: 2021. 02. 05.)

1997. évi CLIV. törvény az egészségügyről https:// net.jogtar.hu/jogszabaly?docid=99700154.tv (letöltve: 2021. 02. 05.)

Az Európai Parlament és a Tanács 2003/88/EK Irányelve a munkaidő-szervezés egyes szempontjairól, 2003. november 4. https://eur-lex.europa.eu/legal-content/HU/ALL/? uri=celex:32003L0088 (letöltve: 2021. 01. 15.)

Bírósági határozatok:

Európai Unió Bírósága (harmadik tanács) ítélete a C-266/14. számú ügyben http://curia.europa.eu/juris/document/document.jsf;jsessionid=05DF721951C6A093E1FBCC8987B190 29? text $=\&$ docid $=167291$ \&pageIndex $=0 \&$ doclang $=$ HU\&mode $=1$ st $\&$ dir $=\& o c c=$ first $\&$ part $=1 \& c i d=71472$ 55 (letöltve: 2021. 01. 17.)

Európai Unió Bírósága (második tanács) itélete a C-254/18. számú ügyben http://curia.europa.eu/juris/document/document.jsf;jsessionid=49F4E50F3AA95C7AFAEC8ECCF3B E36DD? text $=\&$ docid $=212910$ \&pageIndex $=0 \&$ doclang $=$ HU\&mode $=1$ st\&dir $=\& o c c=$ first\&part $=1 \& c i d=$ 10309439 (letöltve: 2021. 01. 17.)

Európai Unió Bírósága (nagytanács) ítélete a C-55/18. számú ügyben http:/ / curia.europa.eu/juris/document/document.jsf?text $=\&$ docid $=214043 \&$ pageIndex $=0 \&$ doclang $=\mathrm{H}$

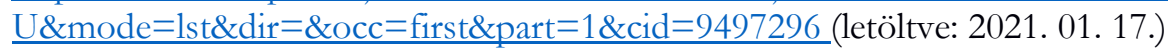

Európai Unió Bírósága (nagytanács) ítélete a C-313/02. számú ügyben 
Debreceni Jogi Múhely 2021. (XVIII.) 1-2.

Debreceni Egyetem, Állam- és Jogtudományi Kar, Debrecen

(University of Debrecen, Faculty of Law, Debrecen)

DOI 10.24169/DJM/2021/1-2/6

http:/ / curia.europa.eu/juris/showPdf.jsf?text $=\&$ docid $=49174 \&$ pageIndex $=0 \&$ doclang $=H U \&$ mode $=1$ st

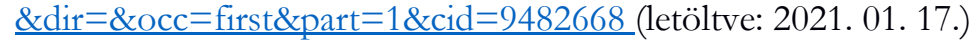

